U.S. DEPARTMENT OF THE INTERIOR

U.S. GEOLOGICAL SURVEY

\title{
MAPS SHOWING THE SEA-FLOOR TOPOGRAPHY OF EASTERN GEORGES BANK
}

By Page C. Valentine, Eric W. Strom, and Carol L. Brown

Prepared in cooperation with the

NATIONAL MARINE FISHERIES SERVICE

MISCELLANEOUS INVESTIGATIONS SERIES

Published by the U.S. Geological Survey, 1992 